\title{
The Development of Teacher Professionalism Towards the Self-Effectiveness of Secondary School Teachers
}

Saadiah Shuib, Jamal@Nordin Yunus

To Link this Article: http://dx.doi.org/10.6007/IJARBSS/v11-i6/10116

DOI:10.6007/IJARBSS/v11-i6/10116

Received: 06 April 2021, Revised: 09 May 2021, Accepted: 29 May 2021

Published Online: 11 June 2021

In-Text Citation: (Shuib \& Yunus, 2021)

To Cite this Article: Shuib, S., \& Yunus, J. (2021). The Development of Teacher Professionalism Towards the Self-Effectiveness of Secondary School Teachers. International Journal of Academic Research in Business and Social Sciences, 11(6), 253-267.

\section{Copyright: (c) 2021 The Author(s)}

Published by Human Resource Management Academic Research Society (www.hrmars.com)

This article is published under the Creative Commons Attribution (CC BY 4.0) license. Anyone may reproduce, distribute, translate and create derivative works of this article (for both commercial and non-commercial purposes), subject to full attribution to the original publication and authors. The full terms of this license may be seen at: http://creativecommons.org/licences/by/4.0/legalcode

Vol. 11, No. 6, 2021, Pg. 253 - 267

Full Terms \& Conditions of access and use can be found at http://hrmars.com/index.php/pages/detail/publication-ethics 


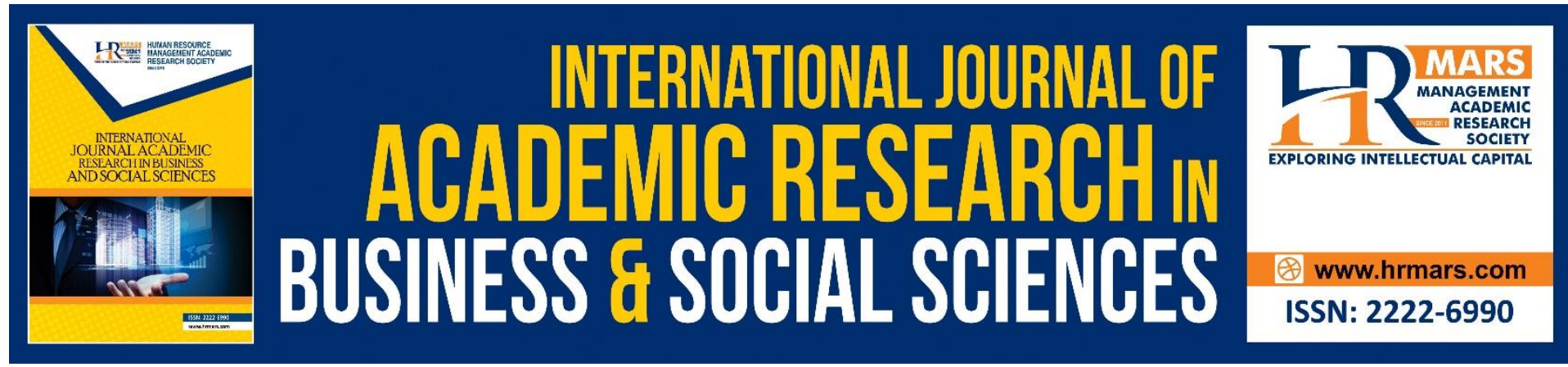

\title{
The Development of Teacher Professionalism Towards the Self-Effectiveness of Secondary School Teachers
}

\author{
Saadiah Shuib, Jamal@Nordin Yunus \\ Sultan Idris Education University, 35900 Tanjung Malim, Perak Malaysia
}

\begin{abstract}
The development of teacher professionalism (PPG) is needed to boost the excellence of school institutions towards continuous and systematic improvement. The process of transformation and innovation desired by the Malaysian Education Development Plan 20132025 (PPPM) is able to realize the world-class Malaysian education system. The study aims to identify the level of PPG practice of secondary school teachers in the state of Selangor (Malaysia) and the implications for teachers' self-efficacy. Data were collected using a questionnaire adapted from the Malaysian Teacher Standard. Stratified random sampling according to the ratio was used in the selection of 384 respondents in this study. Data analysis methods use Statistical Package for the Social Science Version 25 (SPSS) software and descriptive analysis, t-test, variance analysis test (ANOVA), and pearson correlation to determine the influence of teacher professional development on teacher self-efficacy. This study proves that the development of teacher professionalism can increase the level of teacher self-efficacy to a high level. The findings of the study also found that the development of teacher professionalism can be implemented continuously and systematically in schools. The study also proves that there are differences in the level of professional development of teachers according to demographic factors and the findings of this study will be used as a guideline for all stakeholders to implement the development of teacher professionalism in order to increase teacher self-efficacy to a very high level.
\end{abstract}

Keywords: Teacher Professional Development, Teacher Self-Efficiency, Secondary School Teachers, Malaysian Teacher Standards, and Learning Improvement

\section{Introduction}

The teaching profession has long been regarded by society as the most glorious career and provides value and contribution to the development of the nation. Although the appreciation remains, but the current changes are forcing teachers in the 21st Century now for more effort and higher commitment in overcoming the great challenges to teachers in the world of education (Ramlan, 2017). This study aims to identify the level of professional development practice of secondary school teachers and its implications for teachers' self-efficacy. The level of teacher professionalism practice is studied based on the Malaysian Teacher Standards Indicator (SGM) based on three of the thirteen elements, namely Standard i. Values of Teacher Professionalism, ii. Teaching and Learning Skills, and iii. Knowledge and Understanding. This 
descriptive research uses a modified rubric based on SGM and Teacher Self-Efficiency used by (Maulod, 2017).

PPG implementation is divided into several stages, namely planning, implementation, recording, and granting of PPG credit system. Referring to KPM Release Letter. 600-1 / 5/2 Vol. 4 (2) dated 16 January 2019 stipulates the implementation of the credits of Continuous Professional Development (MyPPB) credit that must be achieved by a minimum teacher is 42 credit points. Accordingly, in order to ensure that all cloud employees must ensure that they follow the training that is appropriate to the DG level they have. For example, DG48 teachers who are already competent in their respective fields will be mentors to DG41 and DG44 teachers. This shows that CPD is very important to every civil servant to ensure that they are competent in the field they hold. Every teacher has their own potential to progress to become an excellent teacher or hold a position in the school organization.

Growth-Based Development Training (GOTD) was created to make teachers always proactive and innovative. This is very much in line with the MOE's intention to ensure that teachers placed in schools must always be of high performance and quality to contribute the best service to the school. Schools will not thrive if the teachers placed here do not have the initiative to advance themselves through various means. What is saddest is that there are still teachers who have completed their university education with a static Bachelor's Degree and there has been no change in their development. They should continue to improve themselves and learn and continue to learn up to a higher level. Teachers should take the opportunities provided by the MOE for them to strengthen their careers. To preserve this aspiration, the MOE will ensure that the professional development of teachers becomes the lifeblood of excellence to improve the efficiency of every teacher in a school. Furthermore, this program can improve the quality of service and quality of work that they provide to customers. The Ministry of Education Malaysia (2014) has implemented various efforts to produce quality teachers and ensure that quality people remain in the national education system and remain quality throughout the service period. Various measures have been taken including teacher training, improving the system of teacher candidate selection, boosting the excellence of teacher training institutions, and improving career paths and teacher welfare. Therefore, the Professional Development Program is needed in all organizations whether government or private because it can improve the knowledge and skills of professionals.

\section{Literature Review \\ Professional Development Program}

To ensure that a teacher always masters the knowledge and skills that enable them to compete globally, the Ministry of Education Malaysia (2014) has implemented various efforts to produce quality teachers and ensure that quality people remain in the national education system and remain quality throughout the service period. Various measures have been taken including teacher training, improving the system of teacher candidate selection, boosting the excellence of teacher training institutions, and improving career paths and teacher welfare. KPM has introduced a Continuing Professional Development (PPPB / CPD) development plan, to enhance school-based teacher learning and this is KPM's support for teachers to improve teacher values and uphold the teaching profession. Through the continuous development of professionalism, it is hoped that teachers can modify their teaching and learning methods in line with current developments and students can learn with fun and meaning. This in turn can improve students' academic performance. The learning process of teachers should not stop as far as education at the undergraduate level but should continue by attending trainings, 
briefings, courses and workshops to enhance professional development as long as they serve in the school (Blank, 2014). Continuous and systematic development of teacher professionalism is important to enable teachers to equip themselves with appropriate and up-to-date knowledge, skills and abilities and attitudes (Jantan, 2018).

The development of teacher professionalism is an effective intervention to provide teachers who can follow the rhythm of dynamic educational change. Knowledge is the foundation of concepts and principles related to teaching and learning. Skills, on the other hand, are things that teachers need to have in order to perform their assigned tasks effectively and easily. While ability means the ability of teachers to perform the physical or mental functions required in the task as a teacher in the school (Humanika, 2018). In addition to changes and innovations as well as educational reforms that demand teachers to make themselves effective and proactive in the teaching profession. The Ministry of Education Malaysia in the Malaysian Education Development Plan (PPPM, 2013-2025) formulated by the Ministry of Education Malaysia is a long-term planning and aims to develop integrated schools in the promotion of the teaching profession in Malaysia among the best in the world. Therefore, the government has set a target in the National Key Result Areas (NKRA) of education to produce excellent teachers and school leaders (KPM, 2015). Development of teacher professionalism focused on the field of work based on promotion and improving the teaching ability of teachers to produce quality and excellent teachers (Saad et. al, 2017).

The development of effective teacher professionalism will reduce the gap between individual teachers so that efficiency is more pronounced. The development of teacher professionalism is able to improve teacher skills and improve learning in school organizations (Sani et al., 2015). The development of teacher professionalism is a formal learning process that should be carried out school-based to provide teachers with knowledge and skills and abilities related to the main task areas of teachers namely teaching and learning in the classroom as well as performing tasks and responsibilities to achieve school vision and mission, 2018).

The Master Plan for the Development of Teacher Professionalism (PIPPK) which was introduced in 2016 is to help teachers develop competencies according to their place of work and potential. Competence means teachers must be competent in their tasks listed in the job description to ensure performance standards are met. Model of Educator Talent Management Framework (Sheratt et. al. 2013), used as the basis for the formation of PIPPK. Through PIPPK, the quality of educators will be strengthened through continuous training so that teachers can develop human capital to meet the National Transformation Agenda 2050 (TN50). In this regard, KPM is ready to assist educators with guidance and planning for the development of professionalism on an ongoing basis. The Master Plan for the Development of Teacher Professionalism (PIPPK) is a testament to the MOE's commitment in helping to improve knowledge, skills and values for teachers in Malaysia. Teachers should be more courageous to improve PdPc with knowledge in a proficient, creative and innovative way using the latest technology. Teachers should serve as "role models" by adhering to the work ethic of KPM, teacher ethics and SGM in order to produce educated and ethical human capital (Alis, 2016).

\section{Teacher's Self-Efficacy}

The teacher's self-efficacy in this study refers to a teacher's belief that he or she has the ability to organize and perform a series of actions necessary to complete a teaching task in a more 
specific context. Thus, teacher self-efficacy refers to the teacher's belief in one's ability to teach in a teaching situation. In addition, teacher self-efficacy is a belief built on the ability of teachers to influence students to learn and excellent achievement including students who are less motivated and problematic. Teacher self-efficacy is the key driver to the success of his students. However, this self-efficacy of teachers is broad in its form that combines the beliefs of teachers in general and the beliefs of individual abilities. In this study, researchers used the Teacher Self-Efficacy Model by Shafinaz A. Maulod modified from Tschannen-Moran, Hoy \& Hoy (1998). The effects of Self-Effectiveness that will be analyzed in this study only take three elements, namely i) Effectiveness on teaching strategies, ii) Effectiveness on classroom management and iii) Effectiveness on student involvement.

\section{i) Effectiveness of teaching strategies.}

In this study teaching strategies refer to the way teachers handle and control their teaching process. It relates to the ability of teachers to use teaching strategies to deal with students of different achievement and acceptance and to use various assessment strategies in the classroom. Teacher self-efficacy in this dimension also explains the level of teacher confidence to deal with various levels of questions posed by students.

ii) Effectiveness of classroom management.

Effectiveness of classroom management refers to the teacher's ability to manage the classroom effectively, overcoming student disciplinary problems, the ability to control student behavior resulting in disruption in the classroom and attracting students to comply with classroom rules. In addition, this dimension describes the teacher's confidence to deal with the diversity of student behavior and prevents students from interfering with the learning process.

iii) Effectiveness on student engagement.

Effectiveness on student engagement refers to the self-efficacy of teachers in enhancing student involvement in learning exhibited through behavior and emotions. It also refers to the ability of teachers to attract students' involvement in learning activities to the maximum, to think creatively and critically and to appreciate learning. The effectiveness of student engagement enables teachers to motivate, encourage and give students confidence in their ability to succeed and achieve excellence in lessons.

\section{Influence Between Teacher Professional Development and Teacher Self-Efficacy}

A study of 200 school teachers in India found that the influence of teacher professional development on teacher self-efficacy was high ( $M=7.25, S D=86)$, Azizuddin, Fleva and Qazi (2015). Teachers who have high professionalism, show excellent performance and have high self-esteem will be able to increase their level of self-efficacy ( $M=7.21, S D-88)$. This is in line with the findings of Bandura (1997) who found that teachers who practice professionalism and always improve achievement and are highly motivated to excel have high self-efficacy.

Teachers in the United States who consistently practice professionalism can manage teaching effectively, personal achievement is simultaneous to 243 respondents Brouwers and Tomic (2000). All respondents were able to show significant positive effects on high self-efficacy. However, self-efficacy of teachers has a significant negative relationship to emotional exhaustion among teachers as a result of failure and self-personality disorder is long-term. 
The education system in Turkey is almost identical to the education system in the United States by tightening the conditions for the selection of teachers should be university graduates to ensure a high level of professionalism to improve the self-efficacy of teachers. Therefore, it is important that the concepts and factors that influence the self-efficacy of this teacher are understood by all parties involved in education so that student excellence can be enhanced.

A teacher who practices teacher professionalism must always behave excellently, be able to carry out teaching tasks efficiently and monitor student discipline effectively to produce excellent schools capable of having a high level of self-efficacy. His study found that overall teachers 'self-efficacy was high $(M=3.82)$, as were the three dimensions of teachers' selfefficacy, namely the effectiveness of teaching strategies, the effectiveness of student engagement and the effectiveness of classroom management.

\section{Methodology}

This study uses a quantitative approach with a descriptive survey method using Statistical Package for the Social Science Version 25 (SPSS) software. The population for this study is secondary school teachers who teach in the State of Selangor (Malaysia). Selection of respondents using stratified random sampling technique while sample size includes all five types of school categories available in the State of Selangor, namely National Secondary School, Full Boarding Secondary School, Religious Secondary School, Technical / Vocational Secondary School and Model School Typical. Total sample size was determined using the sample size determination formula by Krejcie and Morgan (1970). The total number of secondary schools in Selangor is 278 but the schools involved in this study are only 30 while the total number of teachers is 35,070 and those involved in this study are only 384 people. According to McMillan \& Schumacher (2006) stratified randomness is acceptable for all specific situations whether for quantitative study or qualitative study.

The questionnaire used is based on the selection of constructs selected from the Standard Guru Malaysia (SGM). The Malaysian Teacher Standard is a standard that outlines the professional competencies that teachers should achieve. The Teacher Education Division (BPG), Ministry of Education Malaysia is responsible for providing Continuous Professional Development such as courses and training for teachers to strengthen the quality of teaching and learning of teachers in schools. Hamjah et al., (2016) stated that a professional teacher in a field should have the qualities (ability, skills, way of implementing something etc.) that must be in a particular field of work that requires education and competence as well as high skills and special training. To ensure that the teachers produced are of high quality, a teacher must have the practice of the value of teacher professionalism, teaching and learning skills and knowledge and understanding. In this study, researchers used a questionnaire in the form of a five-point Likert scale of 1 to 5, namely (1) never, (2) rarely, (3) sometimes, (4) often, and (5) very often. According to Hair (2013) a quantitative research tool that uses questionnaires in the form of questions can measure through the items constructed.

The use of Likert scale items that have been introduced by Likert (1977) is to make it easier for respondents to answer all the questions found in the questionnaire. Researchers believe that the Likert scale produces greater variability and gives justice to all respondents whether negative thinking, natural thinking or positive thinking. The data obtained can be analyzed 
directly by counting, emphasizing and processing it as numbers and easy to generalize to the population (Chua, 2006). Researchers have used the postal service to submit the attached questionnaire together with a cover letter from the Ministry of Education Malaysia and the Selangor State Education Department containing permission to conduct the study and the purpose of the study. Stamped envelopes are also provided to enable the school to send information and action to repost the answers to the questionnaire.

\section{A Propose Research Model}

The research model aims to analyse the relationship between PG and EKG for Malaysian Development. This model is called mediating model as presented in Figure 1.

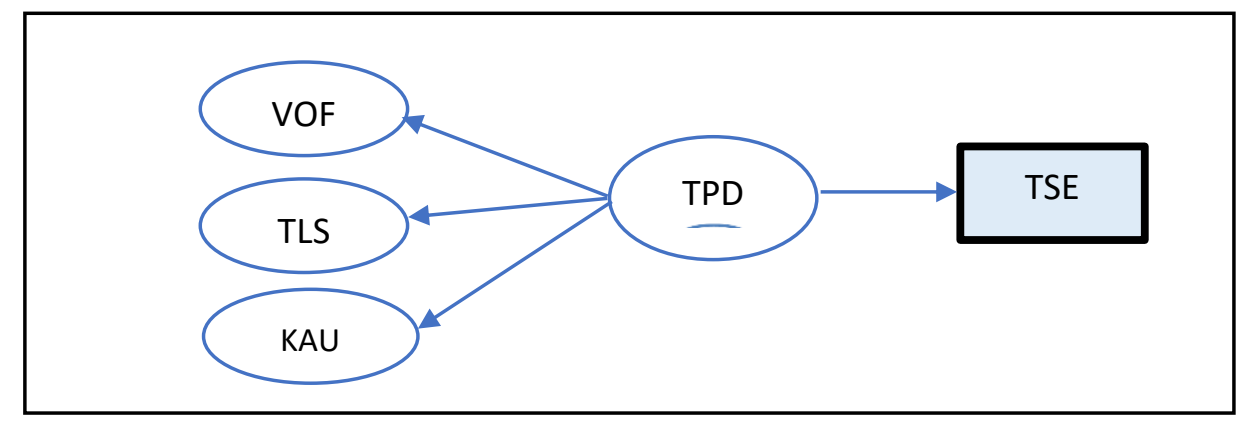

*Notes:

TDP = Teachers Development Professionalism

VOF $=$ practice/value of professionalism

$\mathrm{KAU}=$ knowledge and understanding

TLS $=$ Teaching and learning skills

TSE $=$ Teachers Self-Efficacy

\section{Research Hypothesis}

$\boldsymbol{H}_{1}$ : There is no significant relationship between the Value of Professionalism and the SelfEfficacy of Teachers in Secondary Schools in the State of Selangor.

$\mathrm{Ho}_{2}$ : There is no significant relationship between Teaching and Learning Skills with Teacher Self-Efficiency in Secondary Schools in the State of Selangor.

$\mathrm{Ho}_{3}$ : There is no significant relationship between Knowledge and Understanding with Teacher Self-Efficacy in Secondary Schools in the State of Selangor

Ho4: There is no significant relationship between Teachers Profesionalism Development with Teacher Self-Efficacy in Secondary Schools in the State of Selangor.

\section{Analysis and Discussion}

\section{Respondent Profile Descriptive Statistic}

The first aspect investigated general background of respondents, using descriptive analysis that is by looking at frequency and percentage. The respondents of the study consisted of 384 Secondary School Teachers to express their perceptions of the development of teacher professionalism towards self-effectiveness. 
Table 4.2: Profile of Study Respondents (Teachers)

\begin{tabular}{|c|c|c|c|}
\hline Demographic & Variables & Frequency & Percentage(\%) \\
\hline \multirow{2}{*}{ Gender } & Men & 190 & 49.5 \\
\hline & Women & 194 & 50.5 \\
\hline \multirow{6}{*}{ Age } & Total & 384 & 100.0 \\
\hline & $<$ below 40 years old & 202 & 52.6 \\
\hline & $>$ more than 40 years old & 182 & 47.4 \\
\hline & Total & 384 & 100.0 \\
\hline & Secondary School & 108 & 27.8 \\
\hline & Full Boarding Secondary School & 92 & 23.7 \\
\hline School & Religious High School & 57 & 14.7 \\
\hline \multirow[t]{3}{*}{ Category } & $\begin{array}{l}\text { Technical/Vocational Secondary } \\
\text { School }\end{array}$ & 81 & 20.8 \\
\hline & Special Model High School & 46 & 11.8 \\
\hline & Total & 384 & 100.0 \\
\hline District & Gombak & 56 & 14.4 \\
\hline \multirow[t]{10}{*}{ School } & Hulu Langat & 60 & 15.4 \\
\hline & Hulu Selangor & 20 & 5.1 \\
\hline & Klang & 64 & 16.5 \\
\hline & Kuala Langat & 22 & 5.7 \\
\hline & Kuala Selangor & 24 & 6.2 \\
\hline & Petaling Perdana & 70 & 18.0 \\
\hline & Petaling Utama & 32 & 8.2 \\
\hline & Sabak Bernam & 18 & 4.6 \\
\hline & Sepang & 18 & 4.6 \\
\hline & Total & 384 & 100.0 \\
\hline Eligibility & Graduate & 218 & 56.0 \\
\hline \multirow[t]{2}{*}{ Academic } & Not a Graduate & 166 & 42.7 \\
\hline & Total & 384 & 100.0 \\
\hline \multirow{4}{*}{$\begin{array}{c}\text { Period } \\
\text { Experience }\end{array}$} & < below 10 years & 88 & 22.6 \\
\hline & $11-20$ years & 131 & 33.7 \\
\hline & $21-30$ years & 98 & 2.5 \\
\hline & $>$ more than 31 years & 67 & 17.2 \\
\hline & Total & 384 & 100.0 \\
\hline
\end{tabular}

Significant differences in the development of teacher professionalism, based on demographic factors (a) gender, (b) age (c) academic qualifications of teachers in secondary schools in the State of Selangor?

$\mathrm{H}_{\mathrm{o1a}}$ : There was no significant difference in the development of teacher professionalism based on gender demographic factors in the study schools.

Ujian-t Perbandingan development of teacher professionalism berdasarkan Jantina.

\begin{tabular}{lllllll}
\hline Pembolehubah & Jantina & Min & S.P & t & df & Sig \\
\hline DTP & Man & 4.157 & 0.458 & .868 & 382 & 0.476 \\
& Women & 4.11 & 0.468 & & & \\
\hline
\end{tabular}

** Significance at significance level $p<0.05$ (2-tailed) 
Analysis using t-test method was conducted to see the difference in development of teacher professionalism based on gender. Based on Table 4.38, secondary school teachers in the State of Selangor argue that there is no statistically significant difference for the development of teacher professionalism based on teacher gender factors $(t=0.868, d f=382, p=0.476)$ of which $p>0.05$. Therefore, the null hypothesis failed to be rejected because there was no significant difference for the development of teacher professionalism of secondary school teachers in the state of Selangor based on the gender factor of teachers.

$\mathbf{H}_{\mathbf{o 1 b}}$ : There was no significant difference in the development of teacher professionalism based on age demographic factors in the study schools.

Comparative t-test development of teacher professionalism based on age.

\begin{tabular}{lllllll}
\hline Pembolehubah & Jantina & Min & S.P & t & df & Sig \\
\hline DTP & $<$ below 40 & 4.102 & 0.468 & -1.565 & 382 & 0.365 \\
& $>$ more 40 & 4.176 & 0.455 & & & \\
\hline
\end{tabular}

** Significance at significance level $p<0.05$ (2-tailed)

Analysis using t-test method was conducted to see the difference in development of teacher professionalism based on age. Based on Table 4.38, secondary school teachers in the State of Selangor argue that there is no statistically significant difference for the development of teacher professionalism based on teacher age factors $(t=-1.565, d f=382, p=0.365)$ of which $p>0.05$. Therefore, the null hypothesis failed to be rejected because there was no significant difference for the development of teacher professionalism of secondary school teachers in the state of Selangor based on the age factor of teachers.

$\mathbf{H}_{\mathbf{0 1}}$ : There is no significant difference in the development of teacher professionalism in secondary schools in the State of Selangor based on academic qualifications.

Comparative t-test development of teacher professionalism based on academic

\begin{tabular}{lllllll}
\hline Variables & academic & Min & S.P & t & df & Sig \\
\hline DTP & Graduat & 4.101 & 0.452 & -1.743 & 382 & 0.104 \\
& Non Graduat & 4.184 & 0.473 & & & \\
\hline
\end{tabular}

$* *$ Significance at significance level $p<0.05$ (2-tailed)

Analysis using t-test method was conducted to see the difference in development of teacher professionalism based on academic. Based on Table 4.38, secondary school teachers in the State of Selangor argue that there is no statistically significant difference for the development of teacher professionalism based on teacher academic factors $(t=-1.743, d f=382, p=0.104$ ) of which $p>0.05$. Therefore, the null hypothesis failed to be rejected because there was no significant difference for the development of teacher professionalism of secondary school teachers in the state of Selangor based on the academic factor of teachers.

$\mathbf{H}_{\mathrm{o1c}}$ : There is no significant difference in the development of teacher professionalism in secondary schools in the State of Selangor based on school category. 
ANOVA test Comparison of teacher self -efficacy based on school category

\section{5\% Confidence}

Interval for

Std.

Mean

\begin{tabular}{lrrrrrrrr} 
& & & Deviati & Std. & Lower & Upper & Minimu & Maximu \\
& $\mathrm{N}$ & Mean & on & Error & Bound & Bound & m & m \\
\hline Secondary & 11 & 100.88 & 8.9409 & 0.848 & 99.20 & 102.56 & 84.00 & 120.00 \\
School & 1 & 29 & 6 & 64 & 11 & 47 & & \\
Full Boarding & 97 & 99.525 & 8.7667 & 0.890 & 97.75 & 101.29 & 82.00 & 120.00 \\
Secondary & & 8 & 6 & 13 & 89 & 27 & & \\
School & & & & & & & & \\
Religious High & 62 & 99.483 & 9.3066 & 1.181 & 97.12 & 101.84 & 72.00 & 120.00 \\
School & & 9 & 9 & 95 & 04 & 73 & & \\
Technical/Vocati & 85 & 98.247 & 9.7747 & 1.060 & 96.13 & 100.35 & 72.00 & 120.00 \\
onal Secondary & & 1 & 3 & 22 & 87 & 54 & & \\
School & & & & & & & & \\
Special Model & 45 & 96.533 & 12.038 & 1.794 & 92.91 & 100.15 & 72.00 & 120.00 \\
High School & & 3 & 95 & 66 & 64 & 02 & & \\
\hline Total & 40 & 99.287 & 9.5751 & 0.478 & 98.34 & 100.22 & 72.00 & 120.00 \\
& 0 & 5 & 8 & 76 & 63 & 87 & & \\
\hline
\end{tabular}

\section{Analisis Varians}

The dependent variable: teacher self -efficacy

ANOVA

\begin{tabular}{lrrrrr}
\hline & & \multicolumn{2}{c}{ Mean } & \\
& Sum of Squares & \multicolumn{1}{c}{ df } & Square & \multicolumn{1}{c}{ F } & \multicolumn{1}{c}{ Sig. } \\
\hline Between Groups & 723.779 & 4 & 180.945 & 1.993 & 0.095 \\
Within Groups & 35858.159 & 395 & 90.780 & & \\
\hline Total & 36581.938 & 399 & & & \\
\hline
\end{tabular}

Level of Implementation of Teacher Professional Development (TPD) Development Practices

Findings for the level of Teacher Professional Development (PPG) practice in terms of Teacher Professionalism Practices, Knowledge and Understanding, Teaching and Learning Skills are shown in Table 2. Table 2 shows the interpretation of mean scores to determine the level of professional development practice of secondary school teachers in Selangor. The findings of the study indicate that the practice of professionalism development is at a stage of frequent implementation. 
Firure 2: Level of Teacher Professional Development (TPD)

\begin{tabular}{|c|c|c|c|c|}
\hline \multirow{2}{*}{\multicolumn{2}{|c|}{ Interpretation }} & \multicolumn{3}{|c|}{ Frequency and Percentage } \\
\hline & & SD & Min & $\begin{array}{r}\text { Teacher } \\
\text { Profesional } \\
\text { Development }\end{array}$ \\
\hline \multicolumn{2}{|r|}{0.498} & \multicolumn{2}{|r|}{4.07} & $\begin{array}{c}\text { Value of Profesionalism } \\
\text { High }\end{array}$ \\
\hline \multicolumn{2}{|r|}{0.508} & \multicolumn{2}{|r|}{4.05} & $\begin{array}{c}\text { Knowledge and understanding } \\
\text { High }\end{array}$ \\
\hline High & & 0.482 & 4.15 & Teaching and learning skills \\
\hline High & & 0.463 & 4.15 & Total \\
\hline
\end{tabular}

Respondent $(n=384)$

Figure 2 shows the mean scores for teachers' self-efficacy analysis. Based on the results of the analysis of the study data shows that the respondents gave an overall score for teacher selfefficacy which is 4,089 . This shows that the level of self-efficacy of secondary school teachers in the State of Selangor is at a high level $(M=4.280, S P=2.147)$ There is one dimension that is the dimension of student involvement $(M=4.146, S P=0.482)$ has a higher mean score than the overall mean score $(M=4,089)$. Dimensions that have a lower mean score than the overall mean score are the teaching strategy dimensions $(M=4.074, S P=0.498)$ and classroom management $(M=4.048, S P=0.508)$. From this analysis also shows that secondary school teachers in the State of Selangor have a high level of self-efficacy for all three dimensions measured. Findings show that secondary school teachers in the State of Selangor have the highest level of self-efficacy for the dimension of student engagement ( $M=4.146$, $\mathrm{SP}=0.482)$, followed by the dimension of classroom management $(M=4.048, S P=0.508)$ and finally the dimension of teaching strategy $(M=4.074, S P=0.498)$.

Overall, secondary school teachers in Sealngor State have a high level of self-efficacy where each dimension representing the teacher self-efficacy construct is also at a high level. This high level of teacher self-efficacy shows that secondary school teachers in the State of Selangor have high confidence in student involvement.

Table 2

Relationship between Practice of Professionalism and the Self-Efficacy Correlations

\begin{tabular}{lccccl}
\hline & TPD & TSE & KAU & TLS & VOP \\
\hline Value of professionalism & 1 & $.485^{* *}$ & $.945^{* *}$ & $.926^{* *}$ & $.934^{* *}$ \\
Teaching and learning skills & & 1 & $.423^{* *}$ & $.462^{* *}$ & $.476^{* *}$ \\
Knowledge and understanding & & & 1 & $.817^{* *}$ & $.830^{* *}$ \\
Teachers Self-Efficacy & & & & 1 & $.785^{* *}$ \\
Teachers Professional Development & & & & & 1 \\
$\mathrm{~N}$ & & & & & 384 \\
\hline
\end{tabular}

**. Correlation is significant at the 0.01 level (2-tailed). 
$\boldsymbol{H}_{1}$ : There is no significant relationship between the Value of Professionalism and the SelfEfficacy of Teachers in Secondary Schools in the State of Selangor.

The results of the analysis found that the relationship between Value of Professionalism and Teacher Self-Efficacy was significant $(r=0.93, p<0.01)$. This indicates that the relationship shown is at a strong level. These findings indicate that there is a relationship between Value of Professionalism and Self-Efficiency of secondary school teachers in the State of Selangor. This means that the null hypothesis is rejected because there is a significant relationship between Value of Professionalism and the self-efficacy of secondary school teachers in the State of Selangor.

Ho2: There is no significant relationship between Teaching and Learning Skills with Teacher Self-Efficiency in Secondary Schools in the State of Selangor.

The result shows that the correlation coefficient was $(r=0.48, p<0.01)$. This indicates that the relationship shown is at a simple level. These findings indicate that there is a relationship between Teaching and Learning Skills and Self-Efficiency of secondary school teachers in the State of Selangor. This means that the null hypothesis is rejected because there is a significant relationship between Teaching and Learning Skills and the self-efficacy of secondary school teachers in the State of Selangor.

$\mathrm{Ho}_{3}$ : There is no significant relationship between Knowledge and Understanding with Teacher Self-Efficacy in Secondary Schools in the State of Selangor

The value of $(r=0.83, p<0.01)$. This indicates that the relationship shown is at a strong level. These findings indicate that there is a relationship between Knowledge and Understanding wit Teacher Self-Efficiency of secondary school teachers in the State of Selangor. This means that the null hypothesis is rejected because there is a significant relationship between Knowledge and Understanding and the self-efficacy of secondary school teachers in the State of Selangor.

Ho4: There is no significant relationship between Teachers Profesionalism Development with Teacher Self-Efficacy in Secondary Schools in the State of Selangor.

The correlation was found to be $(r=0.79, p<0.01)$. This indicates that the relationship shown is at a strong level. These findings indicate that there is a relationship between Teachers Profesionalism Development with Teacher Self-Efficiency of secondary school teachers in the State of Selangor. This means that the null hypothesis is rejected because there is a significant relationship between Teachers Profesionalism Development and the self-efficacy of secondary school teachers in the State of Selangor.

\section{Conclusion}

The development of teacher professionalism can give teachers skills that will enable them to develop or develop their full potential and make maximum contributions to their respective schools. The development of teacher professionalism should be enhanced and should be further expanded at the school level continuously and not stop at one time only. The development of teacher professionalism should also be used as a culture in helping teachers to equip themselves with basic skills to carry out their respective duties. Teachers need to 
wisely seize the opportunity to gain new knowledge for example when getting an offer to take a course, do not consider the offer as a workload but consider the opportunity as a way for us to expand the knowledge network. Use media and technology facilities as a gateway for us to upgrade our services as effective teachers in teaching. The job of a teacher is very noble in Islam because Islamic scholars state that teachers are murabbi, muallim, muaddib, mudarris alim or ulama. In conclusion professional development is the process by which a teacher makes reflective or self-reflective dialogue and self-criticism of his or her task to help teachers review their teaching practices critically so that they can renew and improve the quality of their teaching and learning.

\section{Corresponding Author}

Saadiah Shuib, Universiti Pendidikan Sultan Idris

Email: sedyiab11@gmail.com.

\section{References}

\section{Journal Article}

Andrew, S. (1998). Self-Efficacy as a Predictor of Academik Performance in Science. Journal of Advanced Nursing. 27, 596-603.

Ashton, P., \& Webb. R. B (1986). Teachers' Sense Of Efficacy, Classroom Behavior And Student Achievement. New York \& London: Longman.

Ashton, P. (1984). Teacher efficacy: A motivational paradigm for effective teacher education. Jurnal of Teacher Education, 35(5), 28-32.

Babbie, E. (2014). The Basic of Social Research (6th ed). USA: Wadworth.

Babbie. E. R. (2001). The practice of social research 9th Edition. Wadsworth Publishing \& Co. Belmont, California.

Bandura, A. (1977). Self Efficacy: Toward an unifying Theory of Behavioral Change. Psycological Review, 84, 191-125.

Bandura, A. (1993). Perceived Self-Efficacy in Cognitive Development and Functioning. Educational Psychologist. 28(2), 117-148.

Bandura, A. (1997). Self-Efficacy. The Exercise of Control. New York: W.H. Freeman and Company.

Bandura, A. (2001). Social Cognitive Theory: An Agentic Perspective. Annual Review of Psychology. 55: 1-26.

Barth, R. (2006). School: Acommunity of leaders, in Liebrman, A. (Deitor), Building a professionla culture in school. New York: Teachers College Press.

Baumfield, V., Hinggins, S., \& Lin, M. (2008). Thingking Through Teaching: Professional Development for Innovation and Autonomy. Education Review. 16(1): 61-67.

Beach, D. M., \& Reinharts, J. (2000). Instructional leadershp. Needham Heights, MA: Allyn \& Bacon.

Bell, B., \& Gilbert, J. 1994. Teacher Development as Professional, Persona and Social Development. Teaching and Teacher Education. 10(5): 483-497.

Berru, B., Daughtrey, A., \& Wieder. A. (2010). Teacher leadership: Leading the way to effective teaching and learning. Retrieved 23 September 2016 from http://www.teachingquality.org/content/teacher-leaderhsp-leading-way-effectiveteaching-and-learning. 
Boyt, T. E., Lusch, R. F., \& Naylor, G. (2001). The role of professionalism in determining job stisfaction in professional services: A stdy of marketing reseaechers. Journal of Service Research, 3(4), 321-330.

Buck, A. (2009). What Makes Great School? $G=(3 p+2(c+r)+m+o) 51$ : A practical formula for success. December Publications. Belfast, Great Britain.

Buck, J. (2008). Leading professional learning commuinities: Voices from research and practice. School Administrator.

Burnham, J. W., \& Sullivan, F. (2010). Leadership and professional development in schools. (Hamidah Baba, Terj.). London, UK: Pearson.

Carlgren. I. (1999). Profesionalism and teachers as designers. Journal of Curriculum Studies. $31(1), 43-56$.

Carpenter, P. S. II. (2009). Professional learning communities: A case study of three elementary schools. Ed. D. Dissertation, Wilmington Universiti (Delaware), United States -Delware. Retrieved May 18, 2019, from Dissertations \& Theses: Full Text database. (Publication No. AAT 3342825).

Catherine, B., \& Robert, B. (2014). Influence of effective leadership on teaching and learning. Journal of Research Initiatives, 1 (2). 1-11.

Chong, E. K. M. (2012). Using blogging to enhance the inititiation of students, moto academic research. Computer \& Educatioan, 55, 798-807

Cohen, J. (1988). Statistical power analysis for the behavioral sciences (2nd ed.). Hillsdale, NJ: Erlbaum.

Cohen, L., Manion, L., \& Marrison, K. (2011). Research Methods In Education (7th Ed). London: Routledge, Taylor \& Rancis Group.

Cohen, L., Manion, L., \& Marrison, K. (2018). Research Methods In Education (7th Ed). London: Routledge, Taylor \& Rancis Group.

Coladarci, T. (1992). Teacher efficacy, supercision and the special education resource room teacher, Paper Presented at The Annual Meeting of The American Educational Research Association. Chicago.

Corcoran, T. B. (2007). Teaching Matters: How State and Local Policymakers Can Improve the Quality of Teachers and Teaching. Philadelphia, PA: Consortium for Policy Research in Education, Universiti of Pennsylvania.

Cozby, P. C. (2009). Methods in behavioral research tenth edition. Mc Graw Hill Higher Education. New York.

Creswell, J. W. (2008). Educational research: Planning, conducting and evaluating quantitative and qualitative research (3rd Edition). Upper Saddle River: Pearson Merill Prentice Hall.

Creswell, J. W. (2009). Research Design: Qualitative, Quantitative and Mixed Methods Approaches (3rd Ed). London: SAGE Publication Inc.

Creswell, J. W. (2014). The selection of a research approach. In Research Design (pp. 3-23).

Hammond, D. L., Wei, R. C., Andree, A., Richardson, N., \& Orphanos, S. (2009). Professional Learning in the Learning Profession: A Status Report on Teacher Development in the United States and Abroad. Washington, DC: National Staff Development Council.

Darling-Hammond, L. (1998). School: Polcy and professionalisme. Dalam Liebrman, A. (Editor), Building a professional culture in schools (hlm). New York: Teachers College Press.

Darling-Hammond, L. (1999). Teacher quality and student achievement: areview of state policy evidence: University of Washington.

Day, C. (1999). Developing teachers: The challenges of lifelong learning. London: Falmer. 
Dembo, M. H., Gibson, S. (1985) Teachers sense of efficacy: An important factor in school. Elementary School Journal, 86, 173-184.

Dessler, G. (1997). Human resource managemant (Cet. 7). Upper Saddle River, NJ: Prentice.

DuFour, Eaker dan DuFour. (2005). On common ground: The power of professional learning communities respond when kids don't learn. Bloomington: Solution Tree (formerly National Education Service).

DuFour, R., \& Marzano, R. J. (2009). High-leverage strategies for principal leadership. Educational Leadership, 66(5). Assosiation For Supervision And Curriculum Development (ASCD).

Fullan. (2006) Change theory A force for school improvement: Centre for Strategic Education Seminar Series Paper No. 15.

Fullan, M. (2007). The Jossey-Bass reader on educational leadership second editon. John Wiley \& Sons. Inc. San Francisco.

Fullan, M (2008). Leading profesional learning, in Munro, J. H. (Editor). Educational leadership: Round table viewpoints, 181-186. New York: McGraw Hill Education.

Fullan, M. (2001). Leading in a cultural of change. Jossey-Bass A Wiley Imprint. San Francisco.

Fullan, M. (2001). The new meanging of educational change (3rd). New York. Teacher College Press.

Fullan, M. (2009). Leadership development: The larger context. Educational Leadership Jorunal. 67 (2).

Fullan, M. G. (1992). Successful school improvement: The implementation perspective and beyond. Buckingham: Open University Press.

Fullan, M., \& Mascall, B. (2000). Human resource issues in education: A literature review. Wellington: New Zealand Ministry of Education.

Humanika, S., Radin, M., \& Yasin, A. M. Z. (2018). The Implementation of the 21st Century Education in Malaysia: A Preliminary Review Perlaksanaan Pendidikan Abad Ke-21 di Malaysia: Satu Tinjauan Awal. Retrieved from www.sainshumanika.utm.my.

Jantan, A. (2018). Teaching and Learning Supervision, Teachers. International Journal of Instruction, 11(4), www.e-ii.netp-ISSN:1694-609x00.513-26

Mohd, A., Nawawi, A. M., \& Ismail, S. N. (2016). Tahap efikasi guru dan hubungannya dengan pencapaian sekolah di sekolah-sekolah menengah dalam daerah Bachok. Proceeding of ICECRS, 1(2016) 312-326, International Seminar on Generating Khowledge Through Research.

Tamuri, A. H., \& Ahmad, A. (2004). Enhanching teacher profesionalism: The tawheedic paradigm. In Ahmad Sunawi Long et. al. The International Seminar on Islamic Thought Proceeding (pp.297-3030). Bangi. Universiti Kebangsaan Malaysia.

Zamri, A. K., \& Nordin, A. R. (2012). An Analysis of the Teachers' Sense of Efficacy Scale within the Malaysian Context using the Rasch Measurement Model. Procedia Social and Behavioral Sciences, 69, 2137-2142. 